\title{
Quality Computer Assisted Mobile Learning (CAML) and Distance Education Leadership in Managing Technology Enhanced Learning Management System (TELMS) in the Malaysian Public Tertiary Education
}

\author{
doi:10.3991/ijim.v3s1.947 \\ Lee Tan Luck \\ MARA University of Technology Johor, Malaysia
}

\begin{abstract}
The success in the implementation of a quality computer assisted mobile learning and distance education in a Technology Enhanced Learning Management System is highly rely on the academic leadership in managing and application of Information and Communication Technology (ICT) in the tertiary level. The effectiveness of its leadership, knowledge, application and management of ICT and learning management system is of utmost important. Successful application and management includes quality and cost effectiveness of universities administration, CAML and distance education leadership development, organizational culture, academic staffs and students' attitude and their commitment towards teaching and learning process, support towards the usage of state of the art techno-educational facilities, availability of ICT resources, maintenance and funding of a Learning Management System. This paper will discuss the above factors, which present a comprehensive framework for the implementation of a quality CAML and distance education environment in ICT application and management in the Malaysian public universities. Selected Fifty-two respondents from two Malaysian public universities which offer e Learning and distance education with Learning Management System were acquired. A survey questionnaire is used to determine the effectiveness of ICT and mobile learning application management. Data from the questionnaires were analyzed by using non-parametric and parametric statistics testing. Results of this study show there is significant different in the CAML and distance education leadership in TELMS and the application of ICT and its management in the Malaysian public universities. The study will also address the implementation elements necessary for transforming the public universities and its CAML and distance education teaching and learning process into an effective and result oriented computer assisted mobile learning management model in public universities.
\end{abstract}

Index Terms-Computer assisted mobile learning, Distance education leadership, Technology Enhanced Learning Management System, Public universities, Quality.

\section{INTRODUCTION}

The strong awareness of the importance of information and communication technology (ICT) in education has encouraged The Malaysian Ministry of Education and educationists throughout the country to explore the possibility of its usage in the computer enhanced teaching and learning process. The introduction of ICT laboratories in all secondary schools throughout the country starting from 1996 is the earliest ICT and e-learning projects by the
Malaysian government (MOE (C) 1996). Until early 1990 s, ICT and e learning application in the Malaysian education system (MES) is still at its infancy stage (Lee et.al, 2006). To most Malaysians, the concept of application of ICT and e learning in teaching and learning is just the usage of prepared guided education shareware and software to teach computer literacy and computer science for form four student who later will sit for the public examination at upper secondary level. Later the introduction of teaching Science and Mathematics in English (EteMS) by using laptop in class, which is another project, introduced by the government in 2002 till 2008 in the primary and secondary school system. All the Malaysian mega techno educational projects has set the platform of computer assisted mobile learning not only for the in-campus but a very good base for the distance and e learning education in the tertiary level when public university start equip themselves with the advance Technology Enhanced Learning Management System (TELMS). Even with the proposal by the government to supply laptops on loan basis to all university students as well as equip wi-fi and broadband facility throughout the country. The main concern in this study is how effective the education leadership in managing of TELMS which will yield quality CAML by using laptops and PDAs in the Malaysian public universities which cater the philosophy of 'Education for All'.

\section{RELATED LIGTERATURE}

The Malaysian government has emphasized the importance of Information Communication Technology (ICT) and interactive computer technology teaching and learning process in the education system. The government has played its role as architect to promote towards the implementation of various ICT and computer enhanced teaching and learning application projects in the education system. The successful application and management of ICT in EteMS (PPSMI) from 2002 to 2008 which cost RM6 Billions covers all primary and secondary schools in the country. Merrill Lynch estimates global expenditure of education and training at over US\$2 trillions and about $15 \%$ of the total expenditure are in the developing world (Stacey, 2000).

The Malaysian government has continue placing a lot of emphasis to bridging the digital divide between urban schools and rural schools of the country in responds to the global development of ICT and knowledge economy. In line with the development of Multimedia Corridor (MSC) 
and realizing the Malaysian Vision 2020, curriculum should change amidst the changing needs of society and the advent of new technologies and the three integral factors that makes it inevitable for the change in the information curriculum centers around the changing societal needs, changing environment and the rapidly changing technologies (Abdullah, 2002)

The Malaysian government is gearing its efforts to stream line the country towards a knowledge base economy (K-Economy). Large amount of funds has been allocated and channeled towards this cause throughout the country. This efforts is to upgrade the ICT literacy and skills of the people, equalizing the distribution of ICT access contents by improving the ICT infrastructure supporting access, namely electricity and telecommunication infrastructures (Computime, August 12, 2002).

With the success of implementation of the technology enhanced teaching and learning in education. Computer literacy is the main concern and booster to further undertaking by the government. All educational institution at elementary till tertiary level in the country were equipped with ICT infrastructure and is connected and wired with latest ICT technologies. This is the Malaysian government's mega initiative and it will be proven a catalyst towards ICT application and management in the education system of the country.

The demand of computers has picking up since the inception of the application in ICT technology in education. For example the personal computer market for the third quarter of year 2002 in the Asia pacific region has the total shipment of 5.6 million units (Computime, November 14.2002).

Technological enhanced and driven teaching and learning process in the curriculum is due to the emerging digital technologies. Indefinitely it has increased the interest in the computerized delivery of education that led to e learning through electronic mail, Internet and intranet, world wide web (www) and multimedia. Alexander (2001) noted that by using technology in learning, this would produce advantages like improving the quality of learning, access to education and training, reduce cost of education and improve the cost-effectiveness. If any of the technology driven learning is to be successfully implemented, that is to follow the above mention ideas. By doing so, the uses of ICT would be able to reach everybody worldwide, cited Sbarca (2000).

Factors such as effectiveness of education leadership, knowledge, application and management of ICT and learning management system are of utmost important. Successful application and management includes quality and cost effectiveness of universities administration, CAML and distance education leadership development, organizational culture, academic staffs and students' attitude and their commitment towards teaching and learning process, support towards the usage of state of the art techno-educational facilities, availability of ICT resources, maintenance and funding of a Learning Management System which contribute to the success of the introduction, application and managing of TELMS to achieve the targeted quality CAML among students from the public universities in Malaysia. It also includes the first four main components of management, which is the planning, and planning cycle, organizing, directing and controlling. The second category consist of the operational process fol- lowed by the third category of factors namely financial allocation disbursements and funding, training, students' prior knowledge and university administrators' prior knowledge of managing ICT and TELMS platform whereas the fourth category of factors which contribute to the effectiveness in application and managing initiatives that include management styles namely leadership. And lastly the fifth category of factors that constitute hardware, software, TELMS platform.

The success of its application and managing depend on the tactfulness of administrator who at least must well verse with some of the characteristics of computer application. This will benefit the tertiary education system of the country. University administrators are the person appointed in charge of commissioning of TELMS education platform management definitely put a lot of pressures on the management perspectives.

Quality and cost effectiveness in the application and managing TELMS is in fact depending much on the administrator. Even- though the government has supply the entire basic necessary infrastructure to university. Administrators are entrusting with duties in restructuring such as organization structure to manage the TELMS platform in university. Administrator has to choose the best management models to manage. The general problems addressed here was how are tasks organized into individual jobs and how are jobs organized into administrative units and how are these combined into departments. The result is the structuring of departments within an organization and each department containing a set of tasks to be performed by personnel in that department.

Would it be adaptive organization, flexible organization, lateral organization, the horizontal corporations and the centerless corporation? Or the virtual organization because technology will enable employees to communicate with other coworkers and customers without being physically located near them? (Overholt, 1997; Byrne, 1993; Pasterneck. and Viscio, 1998).

The fundamental purpose of all the organizational designs is to reduce the bureaucracy that stifles employee creativity and puts an unacceptable distance between the customer and the decision makers in the organization. Such organization pulls out all the stops to capitalize on their human resources, develop partnerships with other organization with common objectives and let the needs of the customer drive the actions of the organization (Dumain, 1991).

Furthermore, most of the management practices of today followed the system perspective, contingency perspectives, contemporary applied perspective and their various models, rather than maintaining the traditional hierarchical structures because many will increasingly make use of alliances among people and organizations (Lewis et.al 2001)

What about administrator's leadership and style in the application and managing the TELMS platform in university? We have to consider the effectiveness of the leadership style because successful implementation depends much on the administrator's leadership. A committed leader will see the successful implementation and fully utilization of TELMS platform. Otherwise it will fail not just because of lack of resources but also because of human factors. It requires the same management commitment as other mission-critical organization-wide initia- 
tives and it needs to be compelling to the audience it targets by offering the learner a resource that is seem to be appealing, valuable and productive to their goals and aspiration (Henri, 2001). The outcome and monetary waste will be tremendous as Morgan and Keegan had estimates that world expenditure an all forms of education especially in ICT will be exceeding \$2 trillion world wide (Sisco System IQ Atlas, 2000).

As a leader in the academic cycle, university administrator should also be able to guide the other academic staffs in the application and management of TELMS platform in the university. The assumptions that leaders carry in their head in the mental pictures of how the world works have a significant influence on how one perceive problems and opportunities, identify courses of action and make choice (Senge, 1990). Leaders will play its leadership role by helping everybody in the organization, oneself included to gain more insightful view of current reality and this is also in-line with a popular emerging view of leaders as coaches, guides or facilitators. Therefore a strong and well-respected leadership with a clearly defined task would get the best result by fairly directive (Lucey, 1995).

The cost, sources, time frame, infrastructure, management process and curriculum is of ultimate important because it is significant towards the implementation CAML in the tertiary system. The government plays its pivotal roles in terms of cost and sources, infrastructure and curriculum. The government has supply and commissioned the basic ICT infrastructures and TELMS platform to university, as resources are needed to carry out the project. Therefore money spent must be well worth to the society as fund comes from the tax payer.

Compare to the North America based research organization IDC which predicts by 2004, computer base learning market will expanded to $\$ 11$ bn and world total spending will have risen from $\$ 6$ bn in 1998 to $\$ 17$ bn in 2004 (Bob Little, 2001). Global expenditure of education and training are over US\$ 2 trilion (Clarke and Hermens, 2001). So the huge expenditure put forward by the government is of utmost important toward the educational course of the country. As administrators who have to carry out the implementation stages in the tertiary education system needs not only to make full usage and application of the technology but also must educate the students and offer innovative programs (Gunasekaran; McNeil and Shaul, 2002).

Support of the education process also are all in the way with key elements inclusive of provision of learning materials, providing facilities for practical work or simulations, enabling questions and discussion, assessments and provision of student support service (Alexander and McKenzie, 1998), all these elements could be find in the education system through government funded as well as private vendors TELMS platform throughout the country.

To date, the country's implementation of ICT and computer base learning application perspective favor to be generating success because the result from students shows the upgrade of achievement towards progressive improvements.

In fact the availability of broadband technology in the country now will increase the active learning options by making use of video conferencing, advance animation technologies and virtual scientific laboratory and of course the latest would be the CAML through TELMS platform in the universities. Electronic books have become more prevalent instead. All this will added values to the existing technology in universities for change especially the education system have already faced the fast-paced culture. By providing internet and intranet facilities or e-learning and distance education solutions to the students, that will be able to turn change into an advantage and allowed people and organization to keep up with dynamic changes in the global perspective.

Internet is beginning to significantly elevate the whole concept of learning, by bringing together richness and extensive reach, developing a move from 'point-driven' learning to learning that support change and transition. (Fry, 2001). So to conclude the cost and sources and resources, time frame and infrastructures and its significant towards the application and management of TELMS platform in universities are more moderate development model has to propose likewise to eradicate the problems of implementation level such as bandwidth, standards and application, culture, difficulties with a piecemeal approach, technical difficulties and lake of infrastructures.

Another significant aspect in application and the management of TELMS platform is the teaching and learning culture. Even though we have a drastic change in terms of transforming academic towards a more technological centered one. But the question pose here are the academic and student community prepare for the change? Sometime traditional and conventional methodology still could be use but because of the challenges from the outside world, we need change. That is change for the better to be transforming towards the technological challenge of the information age.

Learning culture can be analyzed through the relationships between people namely academic staffs, students and society. And of cause through the management of resources which includes physical one like space, and non-physical one like time and people. Due to the fact that ICT is the core of education of future citizen and the kinds of changes designed in each university, how the changes modified the learning culture and the changes that happened in the way academic actually used ICT in their teaching and learning process (Azinian, 2001). So, teaching staffs are the people in the system that could carry out the function to create new learning and teaching culture in preparing students to face the challenging world of fast pace technology such as CAML and PDAs.

The effective change toward the learning culture whereby academic staffs must involved themselves in using the present advancement of ICT technologies and TELMS platform that provided and commissioned in the tertiary level to up-grade themselves towards the usage and applications not only to the teaching and learning process but also to their own learning process by continuing upgrade themselves towards life-long learning concepts and practices. Therefore tertiary institution could be well preferred as learning organization to all its academic staffs.

University administrators, academic still have to prepare them in this perspective because study shown that, students retains their learning for longer periods if academic staffs in universities use multimedia to enhance their classes. So change in teaching and learning culture towards a more technological preferably quality CAML 


\section{QUALITY CAML AND Distance EDUCATION LEADERSHIP IN MANAGING TELMS IN THE MALAYSIAN PUBLIC TERTIARY EDUCATION}

technology is inevitable in the tertiary education system. In term of organizational culture, one has to ask is the organization willing to invest in a paradigm shift from knowledge hoarding to knowledge sharing. Organizations that succeed in knowledge management are likely to view knowledge as an asset sharing of knowledge.

\section{RESEARCH OBJECTIVE}

The objectives of this study are to determine the effective application of TELMS platform in quality CAML and PDAs application in the MES. Figure 1 shows the theoretical framework.

This study also investigates the efficiency of university administrators in managing the TELMS platform and the effectiveness of its usage among students at the tertiary level. It also investigates the quality and cost effectiveness of university's' administration, learning culture, academic staffs and students' attitude and commitment towards the technology enhanced teaching and learning process, support towards the use of educational technology, maintenance of ICT and TELMS platform in universities which affect the effectiveness of the management the quality CAML in an e learning and distance education setting. In addition, other factors are also taken into consideration, e.g. rural or urban students, curriculums and syllabus, managerial and technical support.

\begin{tabular}{|l|l|}
\hline \multicolumn{1}{|c|}{ DEPENDENT VARIABLE } & \multicolumn{1}{|c|}{\begin{tabular}{c}
\multicolumn{1}{c}{ INDEPENDENT } \\
VARIABLES
\end{tabular}} \\
\hline & $\begin{array}{l}\text { Culture (Perception, knowl- } \\
\text { edge, technology transfer, atti- } \\
\text { tude and change) } \\
\text { Management (Management } \\
\text { knowledge, leadership) }\end{array}$ \\
Usage (curriculum) \\
$\begin{array}{l}\text { Quality CAML and Distance } \\
\text { Education Leadership in } \\
\text { Managing TELMS in Public } \\
\text { Universities }\end{array}$ & $\begin{array}{l}\text { Maintenance \& Resources } \\
\text { location, inventory, stocks, } \\
\text { auditing, tangible and intangi- } \\
\text { bles) } \\
\text { Users: Teaching and learning } \\
\text { in CAML (background, prior } \\
\text { knowledge, experience, qualifi- } \\
\text { cation, ICT literacy, course } \\
\text { attended) } \\
\text { Administrators \& academics } \\
\text { (Experience, ICT \& TELMS } \\
\text { platform) }\end{array}$ \\
\hline
\end{tabular}

Figure 1. Framework

\section{RESEARCH METHODOLOGY}

A survey questionnaire was given to 52 university administrators and academic staffs from two selected public university in Malaysia. The questionnaire consists of 79 questions divided into 2 parts: Part 1 consists of questions on the respondent's demographics and Part 2 on the dependent and independent factors. Likert 5-point scale was used for the questions in Part 2. Parametric statistical tests were used to analyze the data.

\section{RESULTS}

\section{A. Reliability of instrument}

Cronbach Alpha statistic is found to be 0.859 ; therefore the reliability of the questionnaire is acceptable.

\section{B. Descriptive Statistics}

TABLE I.

SUMMARY OF RESPONDENTS’ CHARACTERISTICS

\begin{tabular}{|c|c|c|}
\hline SUBJECT & FREQUENCY & $\begin{array}{c}\text { PERCENTILE } \\
(\%)\end{array}$ \\
\hline $\begin{array}{l}\text { 1. GENDERS } \\
\text { Male } \\
\text { Female } \\
\end{array}$ & $\begin{array}{l}25 \\
27\end{array}$ & $\begin{array}{l}48.1 \\
51.9 \\
\end{array}$ \\
\hline $\begin{array}{l}\text { 2. } \quad \begin{array}{l}\text { Respondent's } \\
\text { position held }\end{array} \\
\text { Administrator } \\
\text { Senior academic staff } \\
\text { Academic staff }\end{array}$ & $\begin{array}{c}10 \\
9 \\
33\end{array}$ & $\begin{array}{l}19.2 \\
17.3 \\
63.5\end{array}$ \\
\hline $\begin{array}{lr}\text { 3. RACE } & \\
\text { Chinese } & \text { Malay } \\
\text { dian } & \text { In- } \\
\text { ers } & \text { Oth- }\end{array}$ & $\begin{array}{c}29 \\
16 \\
5 \\
2 \\
\end{array}$ & $\begin{array}{c}55.8 \\
30.8 \\
9.6 \\
3.8 \\
\end{array}$ \\
\hline $\begin{array}{l}\text { 4. Academic } \\
\text { Achievement } \\
\text { Bachelor \& } \\
\text { Master } \\
\text { PhD }\end{array}$ & $\begin{array}{l}32 \\
20\end{array}$ & $\begin{array}{l}61.5 \\
38.4 \\
\end{array}$ \\
\hline $\begin{array}{l}\text { 5. Experience in } \\
\text { Teaching } \\
0-5 \text { years } \\
\text { 6-10 years } \\
11-15 \text { years } \\
10-20 \text { years } \\
>21 \text { years }\end{array}$ & $\begin{array}{c}5 \\
7 \\
18 \\
12 \\
10\end{array}$ & $\begin{array}{c}9.6 \\
13.5 \\
34.6 \\
23.1 \\
19.2\end{array}$ \\
\hline $\begin{array}{l}\text { Experience in } \\
\text { teaching using } \\
\text { ICT } \\
\text { 1-3 years } \\
\text { 4-6 years } \\
>7 \text { years } \\
\end{array}$ & $\begin{array}{c}46 \\
5 \\
1 \\
\end{array}$ & $\begin{array}{c}88.5 \\
9.6 \\
1.9 \\
\end{array}$ \\
\hline $\begin{array}{lll}7 & \text { Attended } & \text { ICT } \\
\text { Course } & \\
\text { Yes } & \\
\text { No } & \\
\end{array}$ & $\begin{array}{c}45 \\
7 \\
\end{array}$ & $\begin{array}{l}86.5 \\
13.5\end{array}$ \\
\hline $\begin{array}{l}\text { 8. Attended Edu- } \\
\text { cation. Man- } \\
\text { agement Course } \\
\text { Yes } \\
\text { No }\end{array}$ & $\begin{array}{l}23 \\
29 \\
\end{array}$ & $\begin{array}{l}44.2 \\
55.8 \\
\end{array}$ \\
\hline
\end{tabular}

Table 1.1 and 1.2 above summarize the respondents' characteristics. They are 25 male (48.1\%) and 27 female $(51.9 \%)$. The composition of race consist of 29 Malay $(55.8 \%), 16$ Chinese $(30.8 \%) 5$ Indian $(9.6 \%)$ and 2 others (3.8\%). Table 1.4 above shows all of the administrators and academic staffs possess high professional qualification in education and Table 1.5 above shows that almost half of the administrators have more than 10 years experience in teaching. Table 1.6 above show $88.5 \%$ of academic staffs experience between $1-3$ years uses ICT in 


\section{QUALITY CAML AND DiSTANCE EDUCATION LEADERSHIP IN MANAGING TELMS IN THE MALAYSIAN PUBLIC TERTIARY EDUCATION}

the teaching and learning process. Tale 1.7 above shows $86.5 \%$ of academic staffs attended ICT courses and they are experience and able in using ICT and TELMS platform very well in their teaching process. Table 1.8 above shows only 44.2 or less than half of the academics and administrators attended educational management course.

\section{INFERENTIAL STATISTICS}

TABLE II.

RESULTS OF PEARSON CORRELATION TESTS.

\begin{tabular}{|c|c|c|c|}
\hline Correlation test between & r & p value & N \\
\hline $\begin{array}{c}\text { Management of TELMS } \\
\text { and students CAML proc- } \\
\text { ess of the two universities }\end{array}$ & 0.455 & $<0.001$ & 52 \\
\hline
\end{tabular}

Note: $\alpha=0.01 ; \mathrm{r}=$ corrélation coefficient; $\mathrm{N}=$ Total respondents.

Table 2 above show there is a moderate and positive relationship between management of TELMS platform and students' application of CAML in the surveyed. The government has funded only the basic ICT infrastructure to surveyed universities. The TELMS platform was acquired by the universities concern from the government allocation. Universities concerns are taking their own initiatives to upgrade the hotspot and wifi facilities to cater the need of the expanding student population. The supply of laptops to academic staffs of universities was stages but the computer laboratories in the universities are connected with internet and intranet system to enable the student to access and learn. However, if the student population were to increase, the government would not consider increase the funding. The 1 administrators had to solicit funds from the various means. Students are using their study loan partially to obtain the laptop to enable them to acquire knowledge through the CAML Therefore the factors for a successful innovation in the teaching and learning should be namely, first the knowledge and application of technology, secondly the supporting infrastructure and thirdly the empowering workers through professionals development.( Szabo, 1996)

TABLE III.

RESULTS OF PEARSON CORRELATION TESTS.

\begin{tabular}{|l|c|c|c|}
\hline Correlation test between & r & p value & N \\
\hline $\begin{array}{l}\text { Academic staffs using the } \\
\text { TELMS in the teaching } \\
\text { and learning process of the } \\
\text { two universities }\end{array}$ & 0.633 & $<0.001$ & 52 \\
\hline
\end{tabular}

Note: $\alpha=0.01 ; r=$ corrélation coefficient; $\mathrm{N}=$ Total respondents

Table 3 above shows there is a strong relationship between academic staffs of the survey universities who upload the teaching materials and teaches students by using TELMS platform. Students are able to learn better when they use the CAML or laptop and PDAs learning through surfing the TELMS platform. Sometime academic staffs of universities and students are the users of ICT in their teaching and learning process by using the ICT Laboratory. Even though, some academic staffs found if difficult and faced the problem of too many users in the ICT laboratories, as the software and hardware provided by the government were limited. This had affected the students' achievement and academic staffs of dissemination of knowledge. Through the TELMS platform, it could get through all registered student in the list. This is the key to a total distance and e learning in tertiary education in Malaysia in the near future.

TABLE IV.

RESULTS OF PEARSON CORRELATION TESTS.

\begin{tabular}{|l|c|c|c|}
\hline Correlation test between & $\mathbf{r}$ & $\mathbf{p}$ value & $\mathbf{N}$ \\
\hline $\begin{array}{l}\text { Universities in Malaysia } \\
\text { and ICT usage Culture. }\end{array}$ & 0.633 & $<0.001$ & 52 \\
\hline
\end{tabular}

Note: $\alpha=0.01 ; \mathrm{r}=$ corrélation coefficient; $\mathrm{N}=$ Total respondents

Table 4 shows that there is strong relationship between the ICT usage cultures in the surveyed universities. That is students' perception towards the academic staffs' usage of ICT to teach in class and in the laboratory. There are many discrepancies in this perspective such as academic staffs' self efficacy in their teaching and learning process. Problem arise here are academic staffs' command of English Language and computer literacy which hinder the progressive of dissemination of knowledge to student.

TABLE V.

RESULTS OF PEARSON CORRELATION TESTS

\begin{tabular}{|l|c|c|c|}
\hline Correlation test between & r & p value & N \\
\hline $\begin{array}{l}\text { Computer Laboratory, } \\
\text { TELMS platform and its } \\
\text { management }\end{array}$ & 0.400 & $<0.003$ & 52 \\
\hline
\end{tabular}

Note: $\alpha=0.01 ; \mathrm{r}=$ corrélation coefficient; $\mathrm{N}=$ Total respondents

Table 5 above shows that there is a moderate relationship between computer laboratory and TELMS platform and its management. Since its inception in 1990s until to date, the responsibilities of ICT laboratory's and TELMS platform maintenance and management are totally relied entirely on the university administrator and ICT coordinator. Success or failures of ICT laboratory and TELMS platform management are relying on the skill of the administrator and coordinator. Many of them even themselves manage to acquire with minimal knowledge of computer technology.

\section{DISCUSSION}

The contributing factors to the effective and quality computer assisted mobile learning and distance education leadership in managing TELMS in quality CAML in the Malaysia public universities are culture, management, usage, maintenance and resources, user that are teaching and learning by CAML and PDAs; administrator and academic staffs. Each of the above mentioned factors is equally important.

A successful and effective application of the TELMS platform facilities in the teaching and learning environment like CAML for the distance and e learning depend very much on the tactfulness of the administrators and academic staffs. Therefore, universities administrators' challenges are to choose the best management models to manage TELMS platform upon the incorporation of this facility. Futrell and Geisert (1984) stated that administrators are entrusted with duties and responsibilities. Administrators not only manage the organization as whole but also other units in that organization. Administrators could 


\section{QUALITY CAML AND DiSTANCE EDUCATION LEADERSHIP IN MANAGING TELMS IN THE MALAYSIAN PUBLIC TERTIARY EDUCATION}

choose the departmental approach as 'Top-Down” organization based upon the grouping of various activities be

cause an organization is a large machine that develops laws and principles, which governed the machine's activities (Lucey, 1995).

TABLE VI.

SUMMARY OF ONE-WAY ANOVA. SIGNIFICANT DIFFERENCE BETWEEN ADMINISTRATORS AND THE EFFECTIVENESS IN APPLICATION AND MANAGING TELMS IN UNIVERSITIES

\begin{tabular}{|c|c|c|c|c|c|}
\hline $\begin{array}{c}\text { MANAGEME } \\
\text { NT OF } \\
\text { TELMS } \\
\text { PLATFORM }\end{array}$ & $\begin{array}{c}\text { Sum of } \\
\text { Squares }\end{array}$ & df & $\begin{array}{c}\text { Mean } \\
\text { Square }\end{array}$ & F & Sig. \\
\hline $\begin{array}{c}\text { Between } \\
\text { Groups }\end{array}$ & 8.901 & 23 & .387 & 3.824 & .000 \\
\hline Within Groups & 2.834 & 28 & .101 & & \\
\hline Total & 11.735 & 51 & & & \\
\hline
\end{tabular}

Note: Value of F Prob. $=.000$. smaller than $\alpha$

Level of 0.05 .

Table 6 above shows there is significant difference between university administrators from the surveyed university in application and managing TELMS in quality CAML effectively. Its significant difference exist among universities may due to the unavailability of the general guidelines provided by the government in managing the appropriate procedure to be practiced. Therefore, the effectiveness in management of TELMS in universities depends much on the administrator's own experience, TELMS platform and management knowledge

A committed administrator will yield the success implementation of quality CAML and TELMS platform. Otherwise it will fail, not because the lack of resources but due to human factors. Successful implementation of quality CAML and TELMS platform needs to be compelling to the audience it targets. Therefore, administrators have to think of a way and means of appealing to academic staffs and students to apply technology especially the computer technology in the teaching and learning process.

Leaders will play their roles by helping everybody in the organization, including gaining more insightful view of current reality and this is also in-line with a popular emerging view of leaders as coaches, guides or facilitators. Therefore a visionary leadership with a clearly defined task could bring changes towards the successful implementation of quality CAML and TELMS platform in the teaching and learning process.

Hersey and Blanchard (1982) have proved that leadership is a process that influences activities towards achieving the objectives. Thus, administration is a two-pronged system in which solutions are offered and objectives are executed. Therefore, administrator is an individual who creates conducive working environment for his employees to strive towards excellence.

Table 7 shows there is a significant difference between the management of TELMS platform and effectiveness in application of quality CAML in universities. The significant difference between the management of TELMS platform in the surveyed universities may due to the administrators' managerial effort towards the increase of the ICT infrastructure. If the users' population increases, infrastructures have to be increase too. Administrators' duty is to overseer adequate ICT infrastructure and its effective utilization. Therefore, the significant different may be accounted for the administrator's less effort to equip the university with extra ICT infrastructures and other means. Further more, some administrators may let the ICT coordinator to handle all the problems. Different universities throughout Malaysia have its own ways of handing and manage the TELMS platform because there is no standard procedure of managing it.

TABLE VII.

SUMMARY OF ONE-WAY ANOVA. SIGNIFICANT DIFFERENCE BETWEEN THE MANAGEMENT OF TELMS AND EFFECTIVENESS IN ITS APPLICATION AND MANAGEMENT IN UNIVERSITIES.

\begin{tabular}{|c|c|c|c|c|c|}
\hline $\begin{array}{c}\text { ADMINIS } \\
\text { TRATOR }\end{array}$ & $\begin{array}{c}\text { Sum of } \\
\text { Squares }\end{array}$ & df & $\begin{array}{c}\text { Mean } \\
\text { Square }\end{array}$ & F & Sig. \\
\hline $\begin{array}{c}\text { Between } \\
\text { Groups }\end{array}$ & 6.527 & 23 & .284 & 5.155 & .000 \\
\hline $\begin{array}{c}\text { Within } \\
\text { Groups }\end{array}$ & 1.541 & 58 & .055 & & \\
\hline Total & 8.068 & 51 & & & \\
\hline
\end{tabular}

Note: value of F Prob. $=.000$, which is smaller than $\alpha$ level of 0.05 .

In any organizations, workforce and human resources is the key in developing the organization. Nisbitt (1994) has listed ten characteristics in restructuring an organization. These traits are applicable in any situations; quality, intuitive beliefs, ideal leadership aptitude and gratuity towards the productivity.

TABLE VIII.

SUMMARY OF ONE-WAY ANOVA. SIGNIFICANT DIFFERENCE BETWEEN MAINTENANCE OF ICT LABORATORY AND TELMS PLATFORM IN UNIVERSITIES AND THE EFFECTIVENESS IN APPLICATION AND MANAGEMENT IN UNIVERSITIES

\begin{tabular}{|c|c|c|c|c|c|}
\hline $\begin{array}{c}\text { MAINTE } \\
\text { NANCE }\end{array}$ & $\begin{array}{c}\text { Sum of } \\
\text { Squares }\end{array}$ & df & Mean Square & F & Sig. \\
\hline $\begin{array}{c}\text { Between } \\
\text { Groups }\end{array}$ & 27.209 & 23 & 1.183 & 2.711 & .006 \\
\hline $\begin{array}{c}\text { Within } \\
\text { Groups }\end{array}$ & 12.220 & 28 & .436 & & \\
\hline Total & 39.430 & 51 & & & \\
\hline
\end{tabular}

Note: Value of F Prob. $=.006$. smaller than $\alpha$ Level of 0.05

Table 8 above shows that there is a significant difference between the maintenance of ICT in the laboratory and TELMS platform which includes selection of the location, stocks and inventory, safety measures and auditing from the universities. The significant different between maintenance of ICT laboratory and TELMS platform in universities may be due to administrators lack of ICT maintenance knowledge. Therefore, the maintenance duty has to be delegate to ICT coordinators and a lot of discrepancy occurs.

Administrators have to be ready by providing the best location, inventory, stock and auditing system to reduce wastage or delay when users are involved in the teaching and learning process.

The increase of users in universities have prompted administrators' to adopt a more moderate approach by seeking extra funding from individuals or other means. This may accommodate extra bandwidth to their existing technology as John Chambers of CISCO System said 'by sticking to the two fundamental equalizers in life namely internet and education', to fuse the two, it provides an 
efficient way to empower workforce with the skills and knowledge it needs to compete amid the rapid pace of change where knowledge management involves a mix of cultural, organizational, process, management and technology initiatives (Wild, Griggs and Downing, 2002).

Therefore knowledge gain by users through quality CAML through the distance and e-learning application empowers them to know more and learn faster with less cost, and to harness the power of information and knowledge which can result in greater productivity, increase profitability and enhance employees' loyalty (Gunasekaran, 2002)

TABLE IX.

SUMMARY OF ONE-WAY ANOVA. SIGNIFICANT DIFFERENCE BETWEEN TEACHING AND LEARNING CULTURE AND EFFECTIVE IN APPLICATION AND MANAGEMENT OF TELMS PLATFORM IN UNIVERSITIES

\begin{tabular}{|c|c|c|c|c|c|}
\hline $\begin{array}{c}\text { Teaching and } \\
\text { Learning } \\
\text { Culture }\end{array}$ & $\begin{array}{c}\text { Sum of } \\
\text { Squares }\end{array}$ & df & $\begin{array}{c}\text { Mean } \\
\text { Square }\end{array}$ & F & Sig. \\
\hline $\begin{array}{c}\text { Between } \\
\text { Groups }\end{array}$ & 6.811 & 15 & .454 & 2.369 & .000 \\
\hline $\begin{array}{c}\text { Within } \\
\text { Groups }\end{array}$ & 6.901 & 36 & .192 & & \\
\hline Total & 13.713 & 51 & & & \\
\hline
\end{tabular}

Note: Value of F Prob. $=.000$.smaller than $\alpha$ Level of 0.05

Table 9 above shows there is a significant difference between teaching and learning culture of using CAML and TELMS platform in the teaching and learning process from the surveyed universities. The significant different may be due to users' background, attitude and prior knowledge of ICT application. Administrators will find difficulties in managing TELMS platform and infrastructure if there are no changes in the academic staffs and students' attitude towards the quality CAML technology.

ICT is the core of education of future citizen and the kinds of changes designed in education system, how the changes modified the teaching learning culture and the changes that happened in the way academic staffs actually used ICT in their teaching and learning process. To rid of the existing conventional culture, academic staffs are the agent for change. Therefore, the academic staffs have to transform themselves before they can really transform the teaching and learning culture towards the using of TELMS platform in quality CAML in the teaching and learning process..

Academic staffs must use the advancement of the ICT to up-grade themselves in the teaching and learning process. This can be done by learning organization and lifelong learning concepts and practices. It is important because a total of $97 \%$ of college students today use Internet for research and $70 \%$ use the Internet daily (Hamm, 2000). It will bring cultural change to the tertiary education system.

Learning institution offers various self-development programs in helping the employees to be an expert in their chosen field. This is because the formal education that they received in other learning institutions does not necessarily reveal their ability in the post that they are holding now (Livingston, 1971). Thus, true learning process occurs while they are working in the real office atmosphere (Revans, 1980).
Therefore Cohen (1980) suggested that the training and learning received while they are working will improve their knowledge, stimulate their ability and attitude and their sense of responsibility towards their organization. Senge (1990) also suggested that learning is an on-going process that each individual in the organization has to participate in discovering his or her hidden talents that eventually will lead to success especially providing good and effective service to the general public's and carry out their corporate responsibility towards the success of implementation of all the planned projects for the general public's well being.

Changes of teaching and learning culture are inevitable. One has to ask the willingness of organization to invest in a paradigm shift from knowledge hoarding to knowledge sharing. Organizations that succeed in knowledge management are likely to view knowledge as an asset and to develop organizational norms and values to support the creation and sharing of knowledge (Devenport et.al, 1998).

\section{CONCLUSION AND RECOMMANDATION}

The continuous evaluation of the effectiveness in the application and management of TELMS platform in the Malaysian public universities has to be carrying out to check its maximum utilization and the successful implementation of quality CAML project. The significant difference among the surveyed universities has show signs of inefficiency in the application and managing of LMS platform. The effective deployment of TELMS platform in tertiary education in Malaysia has to be properly planned because ICT come with intranets and extranet which offer a very capable platform for delivering a comprehensive learning and performance support environment and this will incorporates traditional methods as well as technology-led learning. (Young, 2001)

By far Malaysia is one of the front-runners in this region in term of technology usage and application in education. Slowly by inculcating the new techno -education culture, we are able to realize the country's vision. In addition, there are many independent educational portal exist to facilitate the smooth running of quality CAML teaching and learning processes throughout the country.

All public universities should have combined effort and standardize the Learning Management System (LMS) in the dissemination of knowledge towards the adult learners in the country by setting up a standardized ICT and elearning portal under the patronage of the Ministry of Higher Learning.

The quality CAML application and culture have to be synchronizing to that of the most cost effective method because the impacts of TELMS platform uses may well depend on national culture and its specific idiosyncrasies of the economic environment in which they are embedded. (Spanos, et al 2001)

The success in application and managing of TELMS platform in quality CAML in universities require skillful, dynamic, experienced, confident and committed administrators and academic staffs. They make a difference in influencing students' learning and it has been postulated that competency in delivering effective instruction is a function of academic knowledge and skill in the progress of tertiary education. 


\section{QUALITY CAML AND Distance EDUCATION LEADERSHIP IN MANAGING TELMS IN THE MALAYSIAN PUBLIC TERTIARY EDUCATION}

Another recommendation will be the understanding of religion among the administrators especially Islam, because it considers all kinds of activities inclusive of management as ibadah (pious deeds). This is because Islam is a perfect way of life and encompasses all aspects (I'tikad or iman) and human daily conducts (mu'amalat). Thus, man should perform his duty and responsibility with much sincerity and honesty. The effective and quality management in Islam involves two paradigms, namely a vertical line concept and a horizontal line concept. This relation is to fulfill man's duties as a vicegerent of Allah on earth as shown in the Al-Quran's Surah al-Baqarah, verse 30 and 34:

"Indeed, human being is considered to be honorable and special, so he is eligible to manage and plan for themselves and other beings on earth. It is not only to fulfill worldly needs but more to achieve the purity spiritually so as to gain Allah's pleasure (Keredhaan)."

Therefore, in conclusion, success in the implementation of a quality computer assisted mobile learning and distance education in a Technology Enhanced Learning Management System from the Islamic perspectives of management are:-

i. Characteristics of effective and quality Islamic management must follow the concept of syura' so it will be timeless and adaptable

ii. Individual function in effective and quality Islamic management is to submit oneself to Allah's wills

iii.Philosophy of work in effective and quality Islamic management must follow the good intention (alniyyah or nawaitu) because work is considered as 'ibadah'

iv. Motivation in effective and quality Islamic management is to possess what is lawful and commanded by Allah (mardhatillah)

\section{LIMITATION OF STUDY}

The sample size for the survey is small. However, it will be increased in the final study.

\section{ACKNOWLEDGEMENT}

The authors wish to thank the respondents from surveyed universities in this research.

\section{REFERENCES}

[1] Ahmad Kushairi, 2002 Boosting ICT Literacy In Selangor. Computime October 10, 2002 New Strait Time Press, Kuala Lumpur.

[2] Alexander. S. (2001) Technology Usage In Classroom and Distance Learning In Gunasekaran.A; McNeil. R and Shaul. D, (2002). E-Learning: Research And Applications. MCB Univ. Press, Journal: Industrial And Commercial Training, Vol.34, Issue 2. Pp.44-53.

[3] Alexander. S and McKenzie.J, 1998 The Failure of E-Learning in A. Gunasekaran. Journal: Industrial and Commercial Training, Vol.34, Issue 2 Pp.44-53

[4] Azinian, H (2001), Dissemination of ICT and Changes in School Culture. Information and Communication Technology in Education, School of the Future. International Conference on the Bookmark of the School of the Future, (Science Direct.Com) Pp.35-41

[5] Byme.J (1993), The Horizontal Corporation. Business Week. December 20. 1993 Pp.76-81.

[6] Clarke.T, and Hermens.A, (2001), Corporate developments And Strategic Alliances In e Learning. MCB Univ. Press. Journal: Education \& Training, Vol.43. No.4/5. Pp.256-267.
[7] Cohen, A.R.(1995) Effective Organization in Behavior. Homewood, Ill: Irwin.

[8] Computimes, August 2002, New Strait Time Press, Kuala Lumpur.

[9] Computime, October 2002, New Strait Time Press, Kuala Lumpur

[10] Computime, November 2002, New Strait Time Press, Kuala Lumpur

[11] Devenport. T.H et.al, (1998), Organizational Culture in Rosemarry H.Wild, A Framework for E-Learning as a Tool for Knowledge Management. Journal: Industrial management and Data System. Vol.102, Issue 7. Pp.371-380.

[12] Dumain.B, (1991), 'The Bureaucracy Buster,' Fortune, June 17, 1991 Pp.36-50

[13] Futrell and Geisert (1984), ICT Management in School Entrust With duties in McLaurin, D (1994), 'Computer-Assisted Instruction and its Effects on Reading Comprehension of Special Education Students'. Dissertation, Northwest Missouri State Univ, Maryville, Missouri.

[14] Gunasekaran.A; McNeil. R and Shaul. D, (2002). E-Learning: Research And Applications. MCB Univ. Press, Journal: Industrial and Commercial Training, Vol.34, Issue 2. Pp.44-53.

[15] Gill, (2000) in Kate Fry. E-Learning Markets And Providers: Some Issues And Prospects. MCB Univ. Press, Journal Education and Training, Vol.43, Issue 4.Pp.233-239.

[16] Hamm,( 2000) Survey by the Chronicle of Higher Education. in Rosemary H.Wild, A Framework for E-Learning as a Tool for Knowledge Management. Journal: Industrial management and Data System. Vol.102, Issue 7. Pp.371-380

[17] Henri. J, (2001) A Gunasekaran; Ronald McNeil and Dennis Shaul, 2002). E-Learning: Research and Applications. MCB Univ. Press, Journal: Industrial and Commercial Training, Vol.34, Issue 2. Pp.44-53.

[18] Kate Fry, 2001 E-Learning Markets And Providers: Some issues And Prospect. Journal Education And Training. Vol.43, Issue 4 Pp.233-239. MCB Univ. Press.

[19] Kevin Young, (2001) The Effective Development of e Learning. Journal: Industrial And Commercial Training. Vol.33. Issue 1, Pp.5-11.

[20] Lee \& Suhaidi ( 2006), A Study On The Readiness Of e Learning In The Malaysian Secondary School System. Presented in The International Conference on Distance, Collaborative and e Learning, InED and CERC, UiTM. Berjaya Time Square, Kuala Lumpur.

[21] Little. B, (2001), Achieving High Performance Through e Learning. Journal: Industrial And Commercial Training, Vol.33, Issue 6. Pp.203-207.

[22] Livingston, A.(1998) Gain Sharing Encourage Productivity, Nation's Business, January Pp. 21-22

[23] Lucey, T. (1995) Management Information System. ( $7^{\text {th }}$ Edi). Channel Island: The Guernsey Press. Co., Ltd.

[24] Malaysian Smart School Implementation Plan, July 1997. Kuala Lumpur, Ministry Of Education, Malaysia.

[25] Ministry Of Education, July 1997. Smart School Flagship Application. Government of Malaysia

[26] MOE (C) (1996), Ministry of Education, July 1997. Smart School Flagship Application. Government of Malaysia.

[27] Naisbitt, J. (1994)Global Paradox: The Bigger the World Economy, the More Powerful Its Smallest Players. London: Nicholas Brealey Publishing,

[28] Overholt. M,(1998;). Organizational Design in The $21^{\text {st }}$ Century. Journal of Business Strategy, May/ June 1998. Pp.33-35.

[29] Pasternak. B and Viscio.A (1998), The Centerless Corporation: A Model For Transforming Your Organization For Growth And Prosperity, New York: Simon \& Shuster, 1998.

[30] Pamela. L, Stephen. G and Patricia. F., (2001). Management: Challenges In The $21^{\text {st }}$ Century ( ${ }^{\text {rd }}$ Edi.) Ohio, South Western College Publishing 2001.

[31] Raja Abdullah Yaacob (2002), ICT based Information Professionals, Amidst The Knowledge Era: Challenges In Training And Education. Proceeding, International Conference On Linking Technology In The Information Services: Issues and Challenges, 25-26 June 2002, Kuala Lumpur. 


\section{QuALiTy CAML AND Distance EdUCATION LEADERSHIP IN MANAGING TELMS IN THE MALAYSIAN PUBLIC TERTIARY EDUCATION}

[32] Revan, R.W.(1980) Action Learning: The Techniques for Management. London: Blond \& Briggs.

[33] Rosemary Wild, Kenneth Griggs and Tanya Downing, 2002 A Framework for E-Learning as a Tool for Knowledge Management. Journal: Industrial management and Data System. Vol.102, Issue 7. Pp. $371-380$

[34] Senge, P.(1990), The Fifth Discipline. The Arts And Practice Of The Learning Organization. New York: Doubleday, Random House.

[35] Sbarca, (2001) in Kate Fry. E-Learning Markets and Providers: Some Issues and Prospects. MCB Univ. Press, Journal Education and Training, Vol.43, Issue 4.Pp.233-239.

[36] Sisco System IQ Atlas, 2000 in Kate Fry. E-Learning Markets And Providers: Some Issues And Prospects. MCB Univ. Press, Journal Education and Training, Vol.43, Issue 4.Pp.233-239

[37] Stacey (2000), Global Expenditure of ICT in Thomas Clarke and Antoine Hermens. Corporate Developments and Strategic Alliances In e Learning. MCB Univ. Press. Journal: Education \& Training, Vol.43. No.4/5. Pp.256-267.
[38] Szabo, M. (1996), Interactive Multimedia As Faculty Renewal And Change Agent: A Three-Pronged Approach to Successful Implementations In Malaysia. Kuala Lumpur: EduComp. Pp.5060.

[39] Yiannis E.Spanos, et al 2001 The relationship Between Information And Communication Technologies Adoption And Management. Journal -Information \& Management, Elsevier. Issue 39 (2002) Pp.659-675

\section{AUTHOR}

Lee Tan Luck, is with the Faculty of Business Management, MARA University of Technology Johor, Malaysia.Email:leeta786@johor.uitm.edu.my

This article was modified from a presentation at the International Conference on Interactive Mobile and Computer Aided Learning (IMCL2009) in Amman, Jordan, April 2009. Submitted, May 28, 2009. Published as resubmitted by the author(s) on July 20, 2009. 